\title{
THE UNDERGRADUATE MEDICAL STUDENTS' PITFALLS IN EYE EXAMINATION STATION OF OBJECTIVE STRUCTURED CLINICAL EXAMINATION
}

\author{
Doni Widyandana ${ }^{1,2 *}$, Angela Nurini Agni ${ }^{2}$, Agus Supartoto ${ }^{2}$ \\ ${ }^{1}$ Department of Medical Education and Bioethics, Faculty of Medicine, Public Health and Nursing, Gadjah Mada University, \\ Yogyakarta - INDONESIA \\ ${ }^{2}$ Department of Ophthalmology, Faculty of Medicine, Public Health and Nursing, Gadjah Mada University, Yogyakarta - INDONESIA
}

\begin{abstract}
Background: High prevalence of eye disorders in Indonesia requires medical doctors to be skillful and well trained in ophthalmologic examination. Undergraduate medical students usually start their clinical simulation practice and ophthalmology assessment in a safe learning environment. Skill laboratory as the learning facility should be evaluated and improved regularly. This study aimed to evaluate student's pitfalls in the eyes OSCE station.

Methods: Descriptive analytic study involving Objective Structured Clinical Examination (OSCE) eye examination station score from $1^{\text {st }}-4^{\text {th }}$ year undergraduate medical students batch 2010 in Faculty of Medicine, Universitas Gadjah Mada, Indonesia $(n=516)$. All checklists' scores were analyzed based on particular sub-scales in every examination topic to explore the most pitfalls made by students in eye examination station during OSCE.

Results: The order average value of each subscale in OSCE are: Doctor patient interaction (88.42), History taking skills (82.44), Professionalism (76.43), Physical Examination (74.62), Diagnosis (60.68), Management of Pharmacotherapy (54.70). The percentage of failed-students (scores $<70$ ) in 1st-4th year OSCE based on topics skills were Year 1: Visual field (5.08\%), Visual acuity (14.21\%), Anterior Segment (2.54\%). 2nd year: IOP by palpation (24.38\%), Visual acuity (9.38\%), Anterior Segment (29.38\%). Year 3: visual field (4.94\%), IOP by palpation (2.47\%), Visual acuity (12.35\%), Anterior Segment (7.41\%), Posterior Segment (22.22\%). Year 4: Comprehensive eye exam (17.95\%).

Conclusions: Students mostly challenged in the skills of diagnosis establishment and pharmacological management. The highest number of failed students in each year OSCE vary from each year. 1st year failed most at visual acuity examination, 2 nd year was anterior segment examination and 3rd year was posterior segment examination. Those three skills need to be enhanced systematically.
\end{abstract}

Keywords: OSCE, pitfall pattern, eye examination, undergraduate students, skill laboratory

\section{ABSTRAK}

Latar belakang: Karena tingginya prevalensi penyakit mata di Indonesia, dokter di Indonesia diharuskan untuk memiliki kemampuan yang mumpuni dalam pemeriksaan fisik mata. Mahasiswa kedokteran memulai pelatihan kemampuan klinis mereka di dalam lingkungan laboratorium keterampilan klinis yang harus dievaluasi dan diperbaiki secara berkala. Penelitian ini bertujuan untuk mengidentifikasi pola kesalahan mahasiswa dalam mengikuti OSCE pada stase mata.

Metode: Analitik deskriptif menggunakan data nilai stase mata mahasiswa pendidikan dokter Fakultas Kedokteran Universitas Gadjah Mada Indonesia angkatan 2010 pada Objective Structured Clinical Examination (OSCE) dari tahun 1-4 (n=516). Semua cek lis penilaian dianalisis berdasarkan sub-penilaian tertentu pada tiap topik yang

*corresponding author, contact: widyandana@ugm.ac.id 
diujikan untuk mengeksplorasi kesalahan yang paling sering dilakukan oleh mahasiswa.

Hasil: Urutan rata-rata tiap sub-penilaian pada OSCE adalah: Interaksi dokter-pasien (88,42), kemampuan anamnesis $(82,44)$, profesionalisme $(76,43)$, pemeriksaan fisik $(74,62)$, diagnosis $(60,68)$, manajemen farmakoterapi $(54,70)$. Persentase mahasiswa yang gagal (nilai < 70) pada tahun 1-4 OSCE dalam topik keterampilan; Tahun 1: lapang pandang (5,08\%), ketajaman visus $(14,21 \%)$, segmen anterior $(2,54 \%)$. Tahun 2: palpasi TIO (24,38\%), ketajaman visus (9,38\%), segmen anterior (29,38\%). Tahun 3: lapang pandang $(4,94 \%)$, palpasi TIO $(2,47)$, ketajaman visus $(12,35 \%)$, segmen anterior $(7,41 \%)$, segmen posterior (22,22\%). Tahun 4: pemeriksaan mata komprehensif (17,95\%)

Kesimpulan: Keterampilan yang paling tidak dikuasai mahasiswa adalah kemampuan diagnosis dan manajemen farmakoterapi. Angka tertinggi kegagalan mahasiswa pada topik keterampilan, bervariasi tiap tahunnya: Tahun 1, pemeriksaan ketajaman penglihatan; Tahun 2, pemeriksaan segmen anterior; Tahun 3, pemeriksaan segmen posterior, sehingga ketiga aspek tersebut perlu ditingkatkan.

Kata kunci: OSCE, pola kesalahan, pemeriksaan mata, mahasiswa, laboratorium keterampilan klinik

\section{INTRODUCTION}

Eye disorders are defined as impaired vision and blindness. According to $\mathrm{WHO}$, prevalence of eye disorders in Indonesia quite high (3.34-5.61\%). The lowest prevalence of eye disorder found in America and Europe by number of $2.91-3.17 \%$. In 2010 , most frequent cause of blindness is cataract ( $51 \%$ the total disorder) followed by glaucoma with $8 \%$ of the total disorder ${ }^{1}$.

Based on the primary health research ${ }^{2}$, prevalence of pterygium, corneal opacities, and cataracts in Indonesia respectively $8.3 \% ; 5.5 \%$, and $1.8 \%$. Despite the prevalence of national blindness decreased by 0.5 percent in six years $(2007-2013)$ this number remains high when compared to other countries. Large amount of eyes disorder caused by multifactor. People tend to consult their health status when any kind of sign and symptoms started coming up. Furthermore, miss-diagnosed of patient also contribute to this problem. Therefore, the quality of eye examination and education by doctors in Indonesia needs to be improved.

General practitioners should be able to understand 20 sorts of eye disorder. This included in 4A level of competence in order to make clinical diagnosis and rigorous management of the diseases independently. Medical students in Universitas Gadjah Mada required to perform comprehensive and thorough eye examination in order to meet
Indonesia Physician Standards of Competence published by Ministry of Health of Indonesia, such as visual acuity, anterior and posterior segment of the eye, and any other examination.

Those competencies could be achieved through safe and standardized learning environment in a form of skills laboratory. Medical institution has been widely initiated and built this facility. Students enabled to learn through cases supported by simulated patient or mannequin. Nevertheless, quality and facility of the skills laboratory differ among medical institution. Scheduled evaluation toward the skills laboratory need to be done in order to maintain student's competence achievement.

In the Faculty of Medicine Universitas Gadjah Mada required educational activity in order to achieve the competence is going through Objective Structured Comprehensive Examination (OSCE), which has been established since 1993. To support student undergo OSCE, medical skills training programs held for the undergraduate students. Skills lab directed in a structured and well-planned manner, using various methods ${ }^{3}$.Skills Lab hold very important role in medical skills as well as preparing students before following the internship program ${ }^{4}$.

OSCE aims to evaluate the skills and attitudes at a higher level for integrated learning ${ }^{5-7}$. A study by Cohen et al., ${ }^{8}$ Gupta et al., ${ }^{6}$ and Zayyan ${ }^{7}$ found that OSCE helps student in procedural 
skills, communication and physical examination. Therefore, students are expected to master better skill and ability in managing the patient.

However, students' failure rate in the OSCE held by Faculty of Medicine Skills Lab remains high. Data from the Skills Lab administrator showed that the percentage of student's failure in the OSCE reached $57.18 \%$. High failure rates may be due to errors and poor performance of students in the eye OSCE station. Prior to students' performance, teaching and learning process need to be warrant in a wellorganized activity. Also, students are demanded to enhance their skills by frequent practice and training. Present study aimed to evaluate pitfalls made by students in the eyes OSCE station in particular.

\section{METHODS}

Analysis and evaluation of OSCE results using descriptive quantitative method by exploring the characteristics and identify student's errors in eye examination station. Participants of the study were $1^{\text {st }}$ to $4^{\text {th }}$-year undergraduate medical students on batch 2010 in Faculty of Medicine, Universitas Gadjah Mada, Indonesia $(\mathrm{n}=516)$. All checklists' scores were analyzed descriptively based on particular subscales. Analysis made in every examination topic to explore most pitfalls made by students in eye examination station during OSCE.

There were 12 kinds of checklist, including 4 checklists in the first year, 4 checklists in the second year, 3 checklists in the third year, and one checklist in the fourth year. The amount of any assessment checklist items varies greatly in the range of 6 to 21 assessment items. Grouping of each checklist item following guideline from OSCE Exam Implementation Guide published by Health Professional Education Quality (HPEQ) Project.
Result of medical student's exam checklist in eye examination station during OSCE $(n=200)$ was explored in detail to examine the pattern of frequent pitfalls made by the students during the span of four year in this undergraduate medical school.

The assessment was done by equalizing value in each checklist item. Equalization method done by dividing each value checklist item with maximum value of each from checklist items and multiplying it by 100 . From the assessment obtained minimum value 0 and maximum score 100 for each of the checklist items.

Furthermore, the test method was using arbitrary Pass Mark system (minimum score is 70). This means that student must acquire minimum score of 70 in all stations to be passed the exam. Students who acquire score $<70$ analyzed in number and calculated by percentage from each group of the examination type each year. Acquired data including at which part the students had enough understanding of the examination, which items were not done perfectly and in which part were the students often forget to perform the examination.

\section{RESULTS AND DISCUSSION}

From 535 checklists, there are 19 units (3.55\%) which were excluded due to incomplete data. Total number of valid checklists were 516 (96.45\%), which consisted of 197 checklists from the 1st year, 160 checklists from the 2 nd year, 81 checklists from the 3 rd year, and 78 checklists from the 4 th year.

Overall, descriptive analysis was done by looking at the student's checklist scores of eye examination from the $1^{\text {st }}$ to $4^{\text {th }}$-year that had previously been grouped based on Health Professionals Education Quality (HPEQ) Project. There are 7 groups or sub-scale assessment that used longitudinal every year in OSCE. An average of seven subscales of the assessment seen in Table 1. 
Table 1. Analytical description of the average value of each subscale

\begin{tabular}{clccrc} 
No & \multicolumn{1}{c}{ Subscale assessment } & Mean & Max & Min & SD \\
\hline 1 & Anamnesis & 82.44 & 100.00 & 33.33 & 17.87 \\
2 & Doctor -patient Interaction & 88.42 & 100.00 & 22.33 & 14.84 \\
3 & Professionalism & 76.43 & 100.00 & .00 & 19.25 \\
4 & Physical examination & 74.62 & 100.00 & .00 & 19.41 \\
5 & Establishing Diagnosis & 60.68 & 100.00 & .00 & 26.18 \\
6 & Management of Pharmacotherapy & 54.70 & 100.00 & .00 & 31.77 \\
\hline
\end{tabular}

The highest score is in the "doctor-patient interaction" item assessment with the total score of 88.42. Doctor-patient interaction and anamnesis also a sub-scale with the highest average value of each item. Lowest value found in the Management of Pharmacotherapy item assessment with score of 54.7 .

\section{Descriptive analysis based on the type of examination}

Descriptive analysis based on 12 kinds of checklists from first year to fourth year. Each of the item has different type of examination checklist, but there are some checklists which have the same type of examination. Thus, regrouping was done from the twelve kinds of checklist based on the type of examination. Grouping and details of the checklist based on the type of examination observed in Table 2 .

Table 2. Details of each type of examination checklist

\begin{tabular}{|c|c|c|c|c|}
\hline No & Checklist type & Year & Examination type & $\begin{array}{l}\text { Average of } \\
\text { examination score }\end{array}$ \\
\hline 1 & Checklist 1 & \multirow{3}{*}{$1^{\text {st }}$ year } & Examination of visual acuity & 85.20 \\
\hline 2 & Checklist 2 & & Examination of anterior segment & 83.15 \\
\hline 3 & Checklist $3 \& 4$ & & Examination of vision & 71.40 \\
\hline \multirow{2}{*}{4} & \multirow{2}{*}{ Checklist $5 \& 6$} & \multirow{4}{*}{$2^{\text {nd }}$ year } & Examination of IOP with palpation & 67.08 \\
\hline & & & Examination of anterior segment & 74.75 \\
\hline \multirow{2}{*}{5} & \multirow{2}{*}{ Checklist $7 \& 8$} & & Examination of vision & 82.49 \\
\hline & & & Examination of anterior segment & 78.81 \\
\hline \multirow{3}{*}{6} & \multirow{3}{*}{ Checklist $9 \& 10$} & \multirow{8}{*}{$3^{\text {rd }}$ year } & Examination of vision & 80.81 \\
\hline & & & Examination of anterior segment & 77.78 \\
\hline & & & Examination of posterior segment & 66.67 \\
\hline \multirow{5}{*}{7} & \multirow{5}{*}{ Checklist 11} & & Examination of vision & 91.11 \\
\hline & & & Examination of anterior segment & 75.56 \\
\hline & & & Examination of posterior segment & 73.33 \\
\hline & & & Examination of IOP with palpation & 60.00 \\
\hline & & & Examination of visual field & 48.89 \\
\hline 8 & Checklist 12 & $4^{\text {th }}$ year & Comprehensive & 63.68 \\
\hline
\end{tabular}




\section{Descriptive analysis on most zero-score item checklist}

According to Harden ${ }^{5}$ and Cohen, ${ }^{8}$ OSCE is a multidimension skills test as a tool to measure student clinical skills competency level. Sloan et al. ${ }^{9}$ described that OSCE is a valid clinical skill measuring device with high reliability. Therefore, by looking at OSCE total score, student's level of clinical skills competency can be assumed. The highest average score for subscale of skills is doctor patient interaction with average of 88.42 on a scale of 0-100. Meanwhile the lowest score is management of pharmacotherapy with average score of 54.70 on a scale of $0-100$. Table 3 shows item in each checklist with most zero score.

Table 3. Item checklist descriptive analysis on most zero score

\begin{tabular}{cllcl} 
No & Type of checklist & \multicolumn{1}{c}{ Item with the most zero score } & $\begin{array}{c}\text { Percentage of } \\
\text { zero score }(\%)\end{array}$ & $\begin{array}{c}\text { Present in the type of } \\
\text { examination }\end{array}$ \\
\hline 1 & Checklist 1 & $\begin{array}{l}\text { Ask the patient to close the eye } \\
\text { which not checked }\end{array}$ & 10.34 & $\begin{array}{l}\text { Examination of visual } \\
\text { acuity }\end{array}$ \\
\hline 2 & Checklist 2 & $\begin{array}{l}\text { Ask the patient to follow the } \\
\text { fingertips movement }\end{array}$ & 26.09 & $\begin{array}{l}\text { Examination of } \\
\text { anterior segment }\end{array}$ \\
\hline 3 & Checklist 3 \& 4 & $\begin{array}{l}\text { Ask the patient to look ahead with } \\
\text { relax }\end{array}$ & 32.26 & $\begin{array}{l}\text { Examination of visual } \\
\text { acuity }\end{array}$ \\
\hline 4 & Checklist $5 \& 6$ & Checked the eye lens with pen light & 35.64 & $\begin{array}{l}\text { Examination of } \\
\text { anterior segment }\end{array}$ \\
\hline 5 & Checklist 7 \& 8 & $\begin{array}{l}\text { Indirect pupillary reflex examination } \\
\text { then swings the pen light to both eyes } \\
\text { Check the eye lens with pen light }\end{array}$ & 30.51 & $\begin{array}{l}\text { Examination of } \\
\text { anterior segment }\end{array}$ \\
\hline 6 & Checklist 9 \& 10 & $\begin{array}{l}\text { Wash the hands Plan of action in } \\
\text { accordance with clinical reasoning }\end{array}$ & 6.06 & $\begin{array}{l}\text { Physical examination } \\
\text { Clinical reasoning }\end{array}$ \\
\hline 7 & Checklist 11 & Examination of visual field & 26.67 & $\begin{array}{l}\text { Examination of visual } \\
\text { field }\end{array}$ \\
\hline 8 & Checklist 12 & Management of Pharmacotherapy & 17.95 & $\begin{array}{l}\text { Management of } \\
\text { Pharmacotherapy }\end{array}$ \\
\hline
\end{tabular}

Based on type of examination, fewest percentage score $<70$ was in the type of eyeball movement examination. Contrary, the most percentage score $<70$ is in the type of examination of anterior segment. Total percentage of students with score $<70$ in all types of examination is equal to $39.34 \%$ of 516 (Table 4 and Figure 1).

Table 4 . Percentage of score $<70$ in $1^{\text {st }}$ year to $4^{\text {th }}$ year students

\begin{tabular}{clc} 
No & \multicolumn{1}{c}{ Examination type } & $\begin{array}{c}\text { Percentage of score } \\
<70(\%)\end{array}$ \\
1 & Examination of visual fields & 2.71 \\
2 & Examination of IOP with palpation & 7.95 \\
3 & Examination of visual acuity & 10.27 \\
4 & Examination of anterior segment & 11.24 \\
5 & Examination of posterior segment & 3.49 \\
6 & Examination of eye movements & 0.97 \\
7 & Comprehensive & 2.71 \\
\hline & Total
\end{tabular}




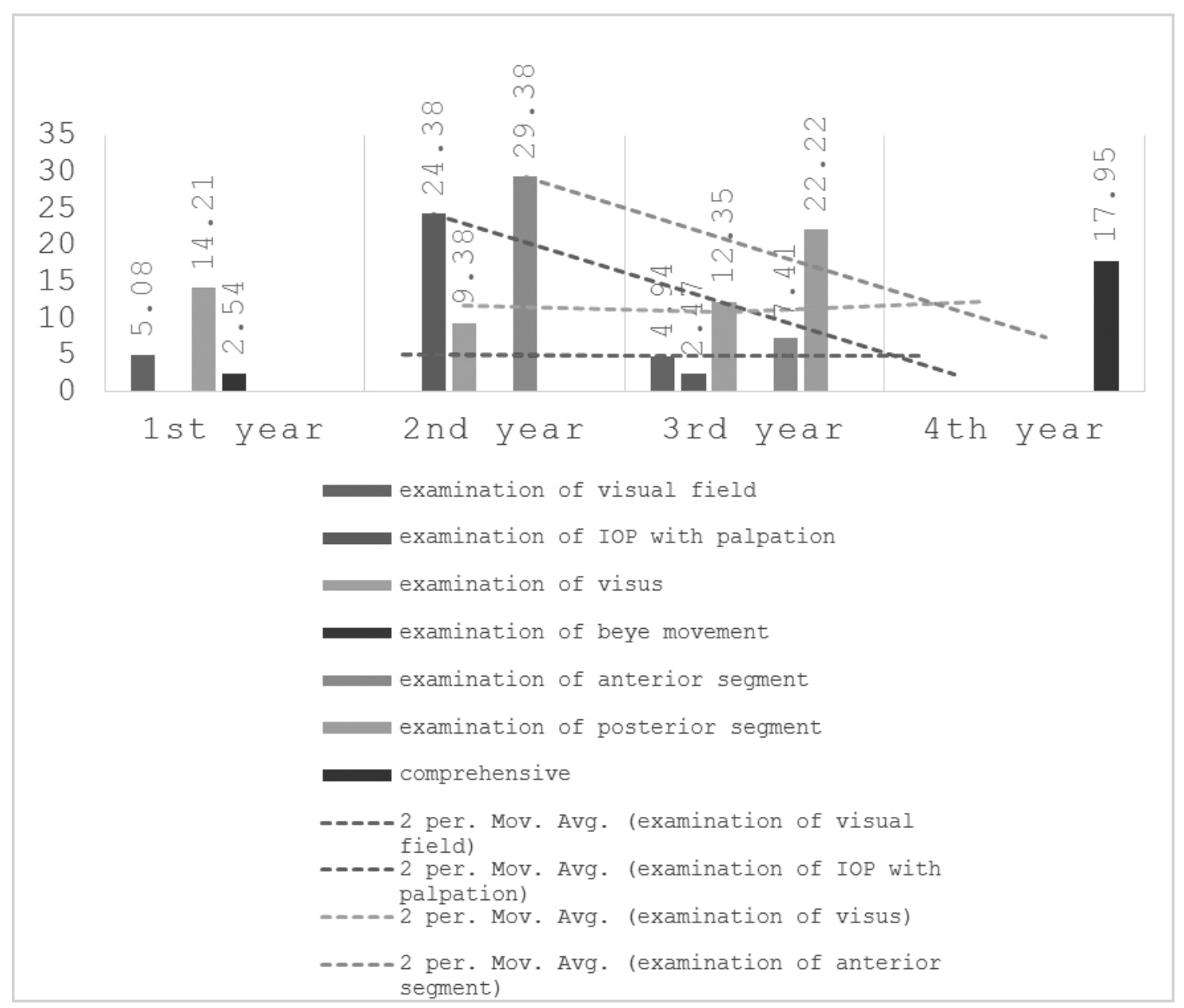

Figure 1. Annual summary of failed students (score $<70$ )

The result indicated that students' ability to interact with patients and the ability to conduct an anamnesis is adequate. This can be associated to the system of Problem Based Learning (PBL) which has been applied in the Faculty of Medicine. Antepohl and Herzig ${ }^{10}$ stated that students with PBL education system had better competence in the field of interpersonal skills. It enables students to establish better relationship with patient.

According to Yuwono et al., ${ }^{11}$ highest readiness level of medical students in Faculty of Medicine, Universitas Gadjah Mada to living professional education lies in the communication skills. The study showed half of the students $(57.2 \%)$ could communicate properly and as much as $54.5 \%$ of all students in the study were able to perform anamnesis to the patient in a real setting. This associated with student's level of confidence in collecting information from patients.

The percentage of students with score $<70$ both in the examinations of visual acuity and visual field examination from the first to the last year tend to remain and had no increments. There was a decrease in the percentage of students who obtained score of $<70$ from the first to the fourth year in the intraocular pressure examination by palpation and anterior segment examination. It indicated the success of learning process managed by the Faculty of Medicine, Universitas Gadjah Mada. It was consistent with a statement proposed by Dreyfus and Dreyfus, ${ }^{12}$ which explained that a learner will go through five stages of skill: novice, advanced beginner, competent, proficient and 
expert. Based on a theory scheme of motor learning by Schmidt, ${ }^{13}$ there were two schemes, recall and recognition scheme. This theory explained that a good skill was strongly supported by the provision of experiences/ practices in the past.

Based on these theories, to achieve a high level of clinical ability a repetitive training was needed. According to the Student Book of the Faculty of Medicine, Universitas Gadjah Mada, ${ }^{14}$ the provision of material and skills evaluation were done gradually: the visual acuity examination was learned during the first year. Examination of the anterior segment of the eye and the repetition of visual acuity examination were done in the second year. Then, the third-year students were introduced to the examination of the posterior segment of the eye, while at the same time made to repeat and recall the previously learned visual acuity examination as well as the anterior segment of the eye examination. OSCE exam was also done gradually throughout the years of medical training. This supported the fact that the teaching methods at the Faculty of Medicine, Universitas Gadjah Mada had reflected on the theories regarding the acquisition of skills by students.

There were several things that had not yet been implemented properly such as pharmacological therapy. As much as $17.95 \%$ of the students did not deliver pharmacologic therapy to patients during OSCE. Sena, Lowe and Lee ${ }^{15}$ and Zeidner ${ }^{16}$ stated that in the exam conditions a person could experience anxiety or anxiety responses in the form of somatic, cognitive and behavioristic. Somatic responses were experienced by students in the form of a cold sweat, trembling, nausea; cognitive response such as loss of concentration and behavioristic response in the form of fear. Due to the loss of concentration, students might forget or deliver inappropriate medicine to patients.

Skills management of pharmacotherapy can be improved by conducting pre-clinical pharmacotherapy context learning. According to Vollebregt et al., ${ }^{17}$ pre-clinical pharmacotherapy context learning had a modest but positive effect on the learning skills of pharmacotherapy when choosing drug therapy and determines the patient information. This effect earned by a roleplaying session between students. Thus, if it is based on such research, pre-clinical application of pharmacotherapy context of learning to students of Faculty of Medicine is expected to increase the ability of the pharmacological management.

First year medical students met obstacle to master visual acuity examination. In the second year, the part that had not yet been mastered was the examination of the anterior segment, while the third year it was the examination of the posterior segment. Based on the Student Book Faculty of Medicine, Gadjah Mada University, ${ }^{14}$ those three type of examination is the essence of examination of each year.

The highest percentage of the score of $<70$ on the entire year is the anterior segment examination with number $11.24 \%$ of total students in this study. The most zero score found in this examination. Eye examination of anterior segment has the highest error level compared with the other types of examination when observed in the entire year of OSCE.

Based on Student Book Faculty of Medicine, Universitas Gadjah Mada, examination of anterior segment of the eye taught in block 2.4 for 2 hours in each session. This examination included anatomy of the outer eye, conjunctival, cornea, pupil and pupillary, and lens. Anterior segment examination does not require high skills but seemingly complicated because many organs had to be examined at a limited time. During the skills laboratory session, due to several students learn in a group the skills are not likely to be practiced by all participants.

Students could practice this examination with peers. Advantage of this method was that division of students into pairs encouraging more focused practice. ${ }^{18}$ Limited time in the learning session related to the failure on the eye examination. Regard to student practice, Adams ${ }^{19}$ proposed a closed-loop motor learning theory. There were two underlying factors to master particular skill: perceptual trace (mimicking what is seen / perceived) and memory trace (follow what is in memory). Based 
on this theory, sufficient time required to perform coaching skills step by step. Additional learning session, outside or inside skills lab and comprised with multimedia as a teaching method could be alternative to attain excellent learning. ${ }^{20}$

In the vision examination, $14.21 \%$ of students did not succeed in doing the skill because they did not perform the simple checklist, ask patients to close their eyes. It was possible that the students experienced stress and anxiety which could disrupt their concentration and made them forget to do the examination items. As stated by Fidment, ${ }^{21}$ stress could affect students' performance.

The results showed that students' ability to carry out some tests is still deficient. Efforts are necessary to follow up this case because OSCE scores could predict performance on a global level and some important competencies of students after graduation. $^{22}$

This study conducted retrospective and focus on an eye examination due to limited OSCE data. Therefore, further prospective studies to evaluate students' pitfalls should be done.

\section{CONCLUSIONS}

This study confirmed that students mostly challenged in the ophthalmology skills of giving pharmacological management and establishing diagnosis. The highest number of failed students in each year OSCE varied; $1^{\text {st }}$ year is visual acuity examination, $2^{\text {nd }}$ year is anterior segment examination, $3^{\text {rd }}$ year is posterior segment examination. Those all needs to be improved for better undergraduate clinical skills training.

\section{RECOMMENDATIONS}

Repetition and recall of the clinical skills need to constantly encouraged upon students. Continuous evaluation in both students' and teachers' performances need to be done. Future research, both quantitative and qualitative regarding learning methods preference and difficulties experienced by the students according to their perspective are recommended.

\section{DECLARATION OF INTERESTS}

Authors declare that there is no competing or possible conflict of interests related to this research.

\section{REFERENCES}

1. World Health Organization. Global Data on Visual Impairment. World Health Organization; 2010.

2. Riskesdas. Laporan Hasil Riset Kesehatan Dasar (Riskesdas). Jakarta: Badan Penelitian Dan Pengembangan Kesehatan RI; 2013.

3. Leddingam IM, Harden RM. Twelve Tips for Setting Up Clinical Skills Training Facility. Medical Teacher, 1998;20(6).

4. Nielsen DG, Moercke AM, Hansen GW, Eika B. Skills Training in Laboratory and Clerkship: Connections, Similarities, and Differences. Med Educ Online, 2003;8(12).

5. Harden, R.M., Stevenson, M., Downie, W., Wilson, G.M. Assessment of Clinical Competence Using Objective Structured Examination. British Medical Journal, 1975;I(1):447-51.

6. Gupta P, Dewan P, Singh T. Objective Structured Clinical Examination (OSCE) Revisited. Medical Education Indian Pediatrics, 2010;47(17):911-20.

7. Zayyan M. Objective Structure Clinical Examination, The Assessment of Choice. Oman Medical Journal, 2011;26(4):219-22.

8. Cohen R, Reznick RK, Taylor BR, Provan J, Rothman A. Reliability and Validity of the Objective Structured Clinical Examination in Assessing Surgical Residents. American Journal of Surgery, 1990;160(3):302-5.

9. Sloan DA, Donnelly MB, Schwartz RW, Strodel WE. The Objective Structured Clinical Examination: The New Gold Standard for Evaluating Postgraduate Clinical Performance. Annals of Surgery, 1995;222(6):735-42. doi:10.1097/00000658-199512000-00007.

10. Antepohl W, Herzig S. Problem-Based Learning Versus Lecture-Based Learning in A Course of Basic Pharmacology: A Controlled-Randomized Study. Medical Education, 1999;33(2):106-13.

11. Yuwono A, Widyandana, Hadianto T. Hubungan antara tingkat kesiapan mahasiswa memasuki pendidikan profesi dengan nilai objective structured clinical examination dan indeks prestasi kumulatif. Jurnal Pendidikan Kedokteran Indonesia, 2009;3(4):152-65. 
12. Dreyfus HL, Dreyfus SE. Expertise in Real World Contexts. Organization Studies, 2005;26(5):779. 92.

13. Schmidt RA. Motor Control and Learning: A Behavioral Emphasis 2nd ed. Champaign, IL: Human Kinetics; 1988.

14. Fakultas Kedokteran UGM. S1 Pendidikan Dokter. [online] Available at: http://fk.ugm.ac.id/2010/05/ program-s1-pendidikan-dokter/ [Accessed 24 Jun. 2015]. Yogyakarta; 2015.

15. Sena JDW, Lowe PA, Lee SW. Significant Predictors of Test Anxiety Among Students with and Without Learning Disabilities. J Learn Disabil, 2007;40(4): 360-76.

16. Zeidner M. Test anxiety: The state of the Art. New York: Plenum; 1998.

17. Vollebregt JA, Van Oldenrijk J, Kox D, Van Galen SR, Sturm B, Metz JCM, Richir MC, De Haan M, Hugtenburg JG, De Vries TPGM. Evaluation of a pharmacotherapy context-learning programme for preclinical medical students. British Journal of Clinical Pharmacology, 2006;62:666-72. doi: 10.1111/j.1365-2125.2006.02742.x.
18. McLean M, Van WykJ. Twelve tips for recruiting and retaining facilitators in a problem-based learning programme. Medical Teacher, 2006;28(8):675-9.

19. Adams, J. A. (1971). A closed-loop theory of motor learning. Journal of Motor Behavior, 3(2), 111-150. https://doi.org/10.1080/00222895.1971.10734898.

20. Xeroulis GJ. Teaching suturing and knot-tying skills to medical students: A randomized controlled study comparing computer-based video instruction and (concurrent and summary) expert feedback. Surgery, 2007;141(4):442-9.

21. Fidment $S$. The Objective Structured Clinical Exam (OSCE) A Qualitative Study Exploring the Health Care Students' Experience. Student Engagement and Experience Journal, 2012; 1(1):1-11.

22. Wallenstein J, Heron S, Santen S, Shayne P, Ander D. A core competency-based objective structured clinical examination (OSCE) can predict future resident performance. Academic Emergency Medicine, 2010;17Supp12. https://doi.org/10.1111/ j.1553-2712.2010.00894.x. 